MARCin PoPIEL

Uniwersytet Jagielloński, Kraków, Polska

\title{
Turystyka osób niepełnosprawnych w gospodarce opartej na wiedzy
}

\section{Accessible Tourism in a Knowledge-based Economy}

\begin{abstract}
Streszczenie: Turystyka osób z ograniczoną sprawnością jest fenomenem, który mocno się rozwija. Jednakże pomimo trwającego rozwoju wciąż - w pewnym stopniu - jest zjawiskiem rzadkim. Wynika to przede wszystkim z braku wiedzy na temat rynku turystów ze specjalnymi potrzebami, braku dialogu, koordynacji i wymiany informacji pomiędzy różnymi szczeblami władzy, przedsiębiorstwami branży turystycznej itp., które współdziałają w ramach gospodarki opartej na wiedzy. Artykuł prezentuje przykłady konkurencyjnych i innowacyjnych projektów na rzecz rozwoju turystyki osób niepełnosprawnych. Przybliżona zostaje również terminologia niepełnosprawności oraz segmentacja rynku turystycznego, który odpowiada na potrzeby osób z dysfunkcjami.
\end{abstract}

\begin{abstract}
Tourism for disabled people is a phenomenon that is strongly growing. However, despite its development still - to some extent - is rare. This is mainly due to the lack of knowledge on the market of tourist with special needs, the lack of dialogue, coordination and exchange of information between different levels of government, businesses, tourism industry, etc. that cooperate with each other in a knowledge-based economy. The paper presents examples of competitive and innovative projects for developing accessible tourism, explains the term of disability and the segmentation of the tourism market, which responds to the needs of people with disabilities.
\end{abstract}

Słowa kluczowe: gospodarka turystyczna oparta na wiedzy; innowacje; turystyka; turystyka osób niepełnosprawnych, usługi

Key words: accessible tourism; innovation; service; tourism, tourism knowledge-based economy

\section{WPROWADZENIE}

Osoby niepełnosprawne mają potrzebę i prawo do podejmowania aktu podróżowania, tak jak reszta społeczeństwa (Darcy, Daruwalla, 1999). Podczas podroży każdy napotyka wiele barier turystycznych, jednakże zauważono, iż bariery te niewspółmiernie oddziałują na turystów o specjalnych potrzebach, jakimi są osoby niepełnosprawne (Kaganek, 2009). Doświadczenie podroży przez osoby z niepełnosprawnością często ograniczane jest przez 
fizyczną obecność barier, takich jak: transport, zakwaterowanie, dostosowane miejsca, atrakcje turystyczne czy też - jakże ważne w dobie gospodarki opartej na wiedzy - bariery informacyjne, np. ogólny brak informacji o potrzebach osób niepełnosprawnych i bezpośredniej obsłudze tych szczególnych klientów. Wynika to często ze słabego wyszkolenia personelu. W związku z powyższym turyści, których poziom wymogów dostępności danej usługi wzrasta wraz ze stopniem niepełnosprawności, często zauważają malejący poziom jakości obsługi świadczonej przez oferentów rynku turystycznego oraz liczbę dostosowanych usług (ryc. 1). Brak informacji jest uważany za jedną z głównych przyczyn, które powstrzymują osoby niepełnosprawne przed wybraniem się w podroż (Buhalis, Darcy, Ambrose, 2012).

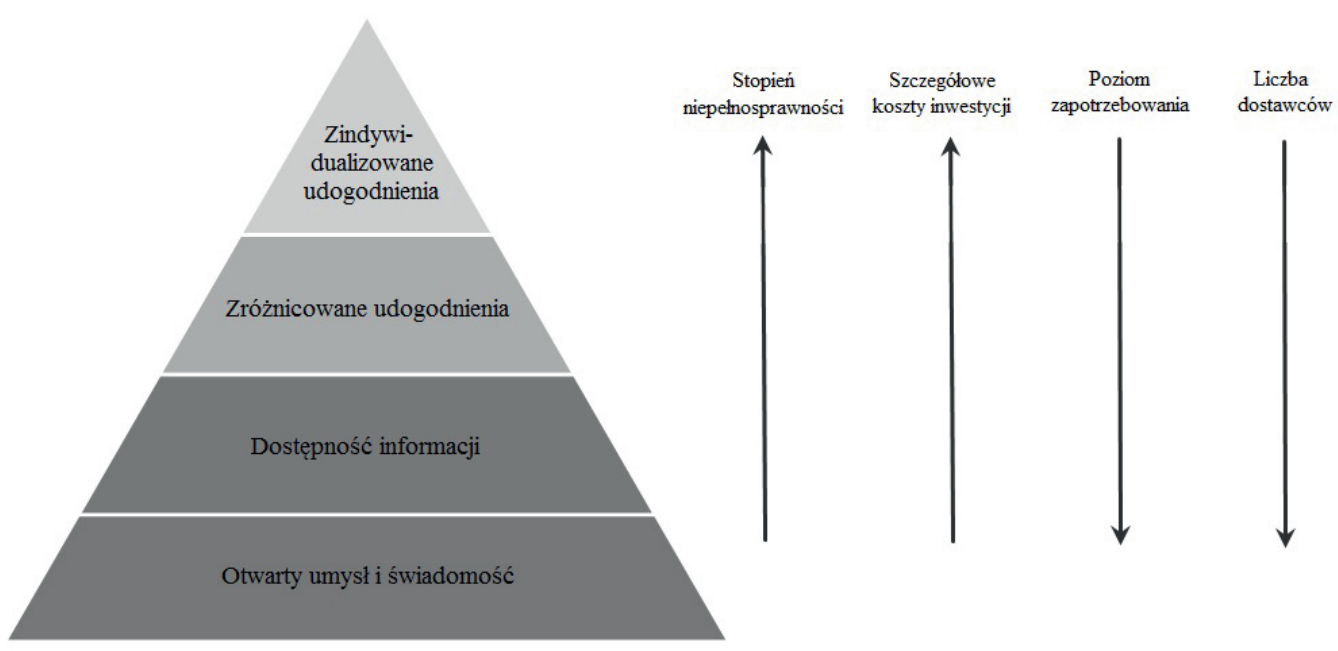

Ryc. 1. Piramida dostępności

Źródło: Economic Impulses on Accessible Tourism for All. (2004). Nr 526. Berlin: Federal Ministry of Economics and Labour, 33

Udział w turystyce osób z dysfunkcjami jest znacznie ograniczony, choć osoby niepełnosprawne mają fundamentalne prawo uczestnictwa $\mathrm{w}$ turystyce na zasadach równości z innymi osobami. Przywilej ten został objęty Konwencją ONZ z dnia 13 grudnia 2006 o prawach osób niepełnosprawnych (art. 30) (www.un.org, dostęp: 12.12.2012). Konieczne są zmiany organizacyjno-prawne, produktowe, instytucjonalne, ułatwiające aktywizację społeczną osób z dysfunkcjami poprzez udział w turystyce. Kształtowanie powyższych innowacji dla rozwoju turystyki osób niepełnosprawnych w dobie przebudowy gospodarki opartej na wiedzy daje możliwość rozwoju społeczno-gospodarczego oraz poprawy konkurencyjności (Januszewska, Nawrocka, 2010). W gospodarce turystycznej opartej na wiedzy osoby niepełnosprawne stają się integralną częścią oferty i tym samym współtwórcami wartości oferowanej na rynku. Społeczeństwa Unii Europejskiej zainicjowały szereg programów wspierających równouprawnienie i wyrównywanie szans pełnego doznawania przyjemności 
podróżowania przez osoby z niepełnosprawnością. Idee te spotkały się z dużym poparciem państw europejskich i do dziś są kontynuowane (Grabowski, 2008).

Celem artykułu jest próba ukazania zarządzania wiedzą i jego wpływu na formowanie innowacyjnych projektów - w przedsiębiorstwach turystycznych, urzędach państwowych, organizacjach pozarządowych - ukierunkowanych na osoby niepełnosprawne na rynku turystycznym. Autor pragnie również przedstawić wyniki badań nad aktywnością turystyczną 250 respondentów z dysfunkcjami oraz 250 badanych bez niepełnosprawności.

Zakres przestrzenny pracy obejmuje kraje członkowskie Unii Europejskiej. Szczególną uwagę zwrócono na Kraków jako miejsce zamieszkania respondentów biorących udział $\mathrm{w}$ badaniu ankietowym.

\section{PoJęCIE NIEPEŁNOSPRAWNOŚCI}

Istnieje problem z jednoznacznym sprecyzowaniem definicji niepełnosprawności, gdyż mają one różny charakter, różną genezę. Mogą być związane z procesem starzenia się społeczeństwa - ciągłym wydłużaniem okresu trwania życia. Przyczyną może być również rozwój przemysłu, komunikacji, postęp techniki, a tym samym zwiększona liczba wypadków. Dodatkowym czynnikiem może być niezdrowy tryb życia - brak ruchu, złe warunki pracy - czy choćby wady wrodzone. W zależności od powyższych przyczyn, niepełnosprawność może mieć różny charakter. Zatem wyjaśnienie zjawiska niepełnosprawności jest trudne, gdyż odzwierciedlane bywa w różnych płaszczyznach życia, jak m.in.: aspekt medyczny, społeczny, ekonomiczny, emocjonalno-psychologiczny czy prawny. Zgodnie z ideą Światowego Programu Działań na rzecz Osób Niepełnosprawnych oraz Standardowych Zasad Wyrównywania Szans Osób Niepełnosprawnych niepełnosprawność jest problemem ogólnospołecznym, a nie tylko problemem jednostki. Poprzez dysfunkcję należy rozumieć relację zdrowia człowieka - z uwzględnieniem jego wieku, płci i wykształcenia - ze środowiskiem, w którym żyje (Ostrowska, 1994).

Najczęstsze terminy, które powiązane są z niepełnosprawnością, to przede wszystkim: inwalidztwo, kalectwo, niesprawność i upośledzenie.

- Niesprawność - wszelka utrata sprawności lub nieprawidłowość w budowie czy funkcjonowaniu organizmu pod względem psychologicznym, psychofizycznym lub anatomicznym (Halemba, Hermaciński, 2009).

- Niepelnosprawność - wynikająca z niesprawności niemożność oraz ograniczenia prowadzenia trybu życia charakterystycznego dla zdrowego człowieka. Według definicji Majewskiego (1995) osoba niepełnosprawna to taka, która odczuwa spore trudności i przykre konsekwencje na płaszczyźnie codziennego życia osobistego i zawodowego, jak również społecznego, które są wynikiem uszkodzenia tudzież obniżenia sprawności organizmu.

- Inwalidztwo - stan wywołany przez chorobę lub kalectwo. Najczęściej mówi się o nim, gdy okres trwania choroby przekracza sześć miesięcy. Skutkiem jest całkowita lub częściowa niezdolność do podjęcia pracy, wywołana długotrwałymi lub stałymi zaburzeniami słuchu, 
wzroku, uszkodzeniem kończyn czy obniżeniem sprawności intelektualnej (Barczyński, 1993). Według Hulka (1969) inwalida to osoba $z$ naruszeniem sprawności organizmu w stopniu, który znacznie utrudnia pobieranie nauki w normalnej szkole, ogranicza codzienne podstawowe czynności, udział w życiu społecznym czy podjęcie pracy zawodowej.

- Kalectwo - całkowite lub znaczne ograniczenie czynności narządu lub konkretnej części ciała. Rozpatrywane jest jako niepełnosprawność podrzędna w stosunku do inwalidztwa, gdyż uszkodzenia w zaburzeniach inwalidzkich są wielorakie, natomiast w przypadku kalectwa dotyczą jednej, konkretnej dysfunkcji.

Obecnie określenia „,inwalida” i „kaleka” często odbierane są jako krzywdzące, stąd przyjęło się używać terminu: „osoba niepełnosprawna”, natomiast na wady zdrowotne pojęcia: „niepełnosprawność”.

Rozpatrując podział niepełnosprawności według rodzaju, wyróżnione zostają:

- osoby z niepelnosprawnością sensoryczną (osoby niewidome, słabowidzące, niesłyszące, słabosłyszące);

- osoby z niepelnosprawnością fizyczną (uszkodzenia narządów ruchu, schorzenia narządów wewnętrznych);

- osoby z niepełnosprawnością psychiczną (upośledzenie umysłowe, niesprawność intelektualna, epilepsja, zaburzenia osobowości);

- osoby z niepelnosprawnością złożoną (więcej niż jedna niepełnosprawność) (Popiel, 2012: 175-176).

\section{TURYSTYKA WŚRÓD OSÓB Z NIEPEŁNOSPRAWNOŚCIĄ}

Przeprowadzono badanie ankietowe porównujące grupy 250 osób pełnosprawnych i 250 osób niepełnosprawnych, zamieszkujących w Krakowie. Zostali oni zapytani o podejmowną przez nich aktywność turystyczną w ciągu ostatnich 12 miesięcy (ryc. 2).

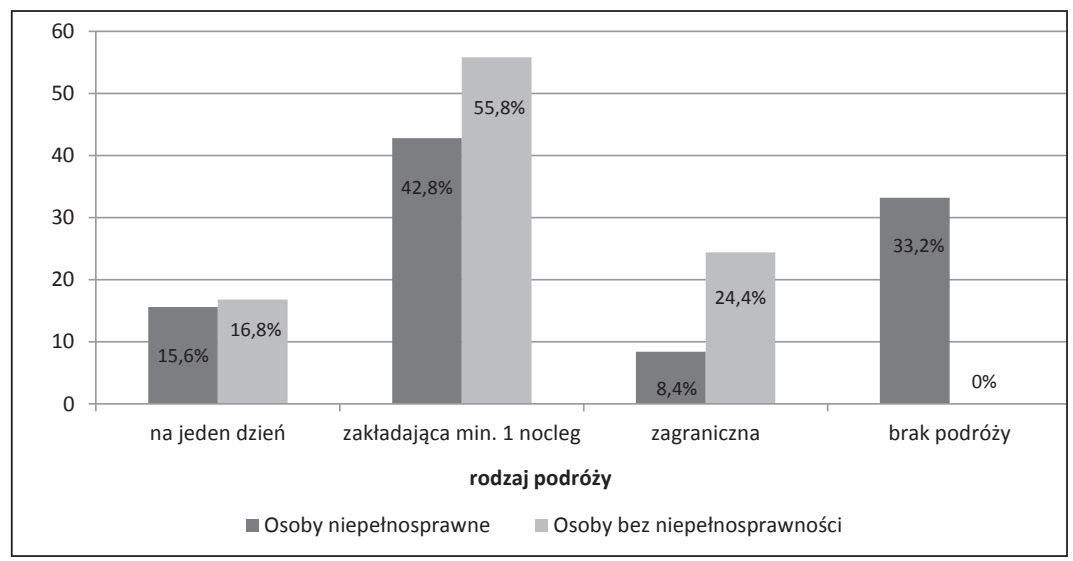

Ryc. 2. Aktywność turystyczna badanych respondentów $(100 \%=250$ osób)

Źródło: opracowanie własne 
Wśród badanych grup osoby niepełnosprawne podróżowały średnio o 1/3 rzadziej aniżeli osoby pełnosprawne. Liczba podróży jednodniowych w obu grupach była na podobnym poziomie $(15,6 \%$ oraz $16,8 \%)$, natomiast podróże zakładające przynajmniej 1 nocleg były wybierane częściej przez osoby zdrowe (55,8\%; osoby niepełnosprawne: 42,8\%). Jest to wynikiem nagromadzenia większej liczby usług turystycznych - m.in.: zakwaterowania, transportu - które winny być dostosowane. Wyjazd zagraniczny podejmowany był częściej przez osoby bez niepełnosprawności $(22,4 \%)$. Osób z dysfunkcją, które by się na taką podróż zdecydowały, było niewiele (8,4\%), gdyż zakłada ona korzystanie z większej liczby usług, które nie zawsze są dostosowane. Osoby niepełnosprawne zazwyczaj akceptują fakt, iż poziom dostępności usług turystycznych nie spełnia ich potrzeb, głównie za sprawą barier architektonicznych, komunikacyjnych, zdrowotnych czy finansowych, zarówno po stronie usługodawcy, jak i usługobiorcy (Burnett, Bender-Baker, 2001). Niejednokrotnie brak dostępności wynika jednak nie z przyczyn finansowych i społecznych, ale z trudniejszych do usunięcia barier typu organizacyjnego i społecznego, w rozumieniu braku wiedzy na temat potrzeb osób niepełnosprawnych. Na rynku turystycznym brakuje odpowiedniego marketingu i informacji dotyczących dostępności istniejących urządzeń turystycznych (Skalska, 2010: 9). Niemiecki rząd - podczas badań nad turystyką osób niepełnosprawnych w Niemczech i wpływie tego segmentu rynku na gospodarkę - skonstruował ranking elementów składających się na łańcuch usług turystycznych (ryc. 3). Respondenci zwrócili uwagę na najważniejsze czynniki, które - ich zdaniem - powinny być w pierwszej kolejności dostosowane do ich potrzeb, oraz te usługi, które są najgorzej dostosowane (tab. 1).

Organizacja (przygotowanie, informacja, rezerwacja)

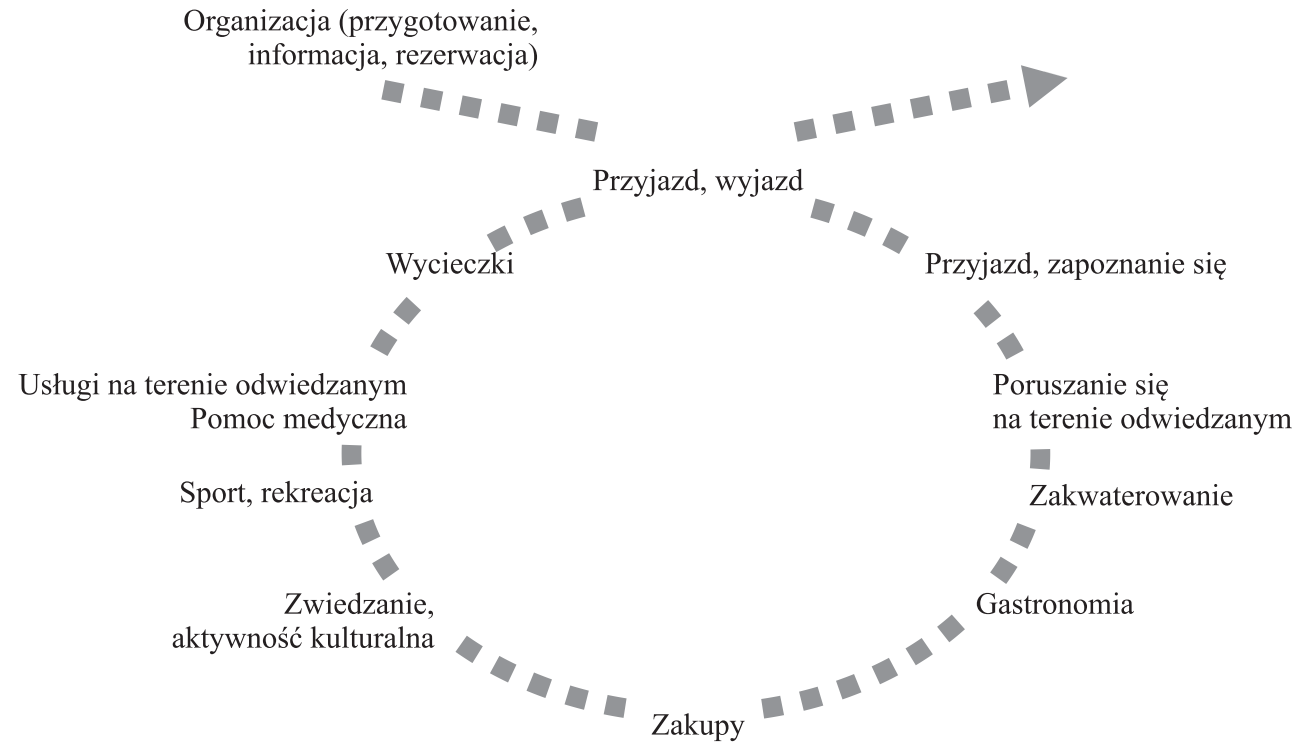

Ryc. 3. Łańcuch usług turystycznych

Źródło: Economic Impulses on Accessible Tourism for All. (2004). Nr. 526. Berlin: Federal Ministry of Economics and Labour, 20 
Tab. 1. Ranking najważniejszych usług turystycznych oraz usług, które są obarczone największymi ograniczeniami z punktu widzenia osób niepełnosprawnych w Niemczech

\begin{tabular}{|c|c|}
\hline Najważniejsze & Obarczone największymi ograniczeniami \\
\hline 1. Zakwaterowanie $(82 \%)$ & 1. Aktywność kulturalna (67\%) \\
\hline 2. Poruszanie się po najbliższym terenie $(76 \%)$ & 2. Poruszanie się po najbliższym terenie $(65 \%)$ \\
\hline 3. Przyjazd/odjazd (74\%) & 3. Wycieczki $(63 \%)$ \\
\hline 4. Wycieczki $(71 \%)$ & 4. $\quad$ Sport $(55 \%)$ \\
\hline 5. Organizacja podróży $(71 \%)$ & 5. $\quad$ Przyjazd/wyjazd (52\%) \\
\hline 6. Aktywność kulturalna (62\%) & 6. Zakwaterowanie $(47 \%)$ \\
\hline 7. Przyjazd/zapoznanie się (61\%) & 7. Przyjazd/zapoznanie się (44\%) \\
\hline 8. Usługi na terenie odwiedzanym (58\%) & 8. Zakupy $(42 \%)$ \\
\hline 9. Opieka medyczna $(52 \%)$ & 9. Usługi na terenie odwiedzanym (42\%) \\
\hline 10. Gastronomia (51\%) & 10. Organizacja podróży $(40 \%)$ \\
\hline 11. Zakupy (37\%) & 11. Opieka medyczna (35\%) \\
\hline 12. Sport $(19 \%)$ & 12. Gastronomia (24\%) \\
\hline
\end{tabular}

Źródło: Economic Impulses on Accessible Tourism for All. (2004). Nr. 526. Berlin: Federal Ministry of Economics and Labour, 20-21

\section{SEGMENTACJA BRANŻY TURYSTYCZNEJ A INNOWACJE}

Branża turystyczna nie jest jednolita, stąd jej segmentacja na mniejsze jednostki. Celem podziału na segmenty jest ustalenie charakterystyki potrzeb i zachowań konsumpcyjnych w celu optymalizacji oferty turystycznej i stworzenie łańcucha wartości (Porter, 2006: 285). W procesie segmentacji rynku turystycznego wykorzystuje się na ogół cztery klasy wyznaczników, stosowanych oddzielnie lub w pewnym zestawieniu. Pomagają one określić nowe produkty, usługi oraz możliwych odbiorców. Dzięki nim ustala się statystyczny punkt widzenia. Wyróżniane przez M.E. Portera (2006) elementy to:

- odmiana produktu;

- typ nabywcy;

- dystrybucja;

- geograficzna lokalizacja nabywcy.

W związku z powyższym w ramach branży turystycznej można wyróżnić rynek turystyki osób niepełnosprawnych, który wymaga specjalnych, zindywidualizowanych odmian usług/produktów i ma specyficzny typ odbiorcy, jakim są osoby z dysfunkcjami. Pod względem lokalizacji i dystrybucji zakłada zasięg globalny, dzięki czemu podróżowanie może się odbywać bez barier na całym świecie.

Wykorzystanie danych na temat potrzeb osób niepełnosprawnych na rynku turystycznym - napotykanych barier i ograniczeń - w procesie personalizacji informacji przekształcane jest 
w wiedzę, a następnie w mądrość. Produktywne wykorzystanie zależne jest od sprawnego zarządzania wiedzą i tworzy innowacje ułatwiające osobom niepełnosprawnym podróżowanie bez barier. Proces tej ewolucji został zaprezentowany na rycinie 4.

\begin{tabular}{|c|c|c|c|}
\hline Dane & $\begin{array}{l}\text { Personalizacja } \\
\text { i nformacji }\end{array}$ & Viedza & Mądrość \\
\hline $\begin{array}{l}\text { - osoby } \\
\text { niepełnosprawne } \\
\text { - potrzeby } \\
\text { - bariery } \\
\text { - ograniczenia }\end{array}$ & $\begin{array}{l}\text { - badania } \\
\text { - odkrycia } \\
\text { - przeżycia } \\
\text { - doświadczenie } \\
\text { - edukacja } \\
\text { - intuicja człowieka }\end{array}$ & $\begin{array}{l}\text { - informacja } \\
\text { wzbogacona } \\
\text { o doświadczenie } \\
\text { - kontekst } \\
\text { - interpretacja } \\
\text { - refleksja }\end{array}$ & $\begin{array}{l}\text { - produktywne wykorzystanie } \\
\text { zależne od sprawności } \\
\text { zarządzania wiedzą } \\
\text { - efektem powinny być } \\
\text { innowacje ulatwiające } \mathrm{ON} \\
\text { podróżowanie bez barier }\end{array}$ \\
\hline
\end{tabular}

Ryc. 4. Proces przetwarzania danych o osobach niepełnosprawnych (ON) w mądrość

Źródło: opracowanie własne

Organizacja rozwija się, tworząc innowacje produktowe (Januszewska, Nawrocka, 2010). Z punktu widzenia marketingu innowacja to zastosowanie nowych pomysłów, rodzajów polityki rynkowej, sposobów dystrybucji i promocji, technologii, wejścia na nowe segmenty rynku, wypuszczenie nowego produktu lub jakakolwiek świadoma, istotna zmiana elementu marketingu stosowana przez organizacje czy przedsiębiorstwa (Repetowski, 2008: 173).

A.-M. Hjalager (2010) wyróżnia pięć rodzajów innowacji w turystyce: 1) innowacje produktowe (usługowe), 2) innowacje procesowe, 3) innowacje w zarządzaniu, 4) innowacje marketingowe oraz 5) innowacje instytucjonalne (ryc. 5).

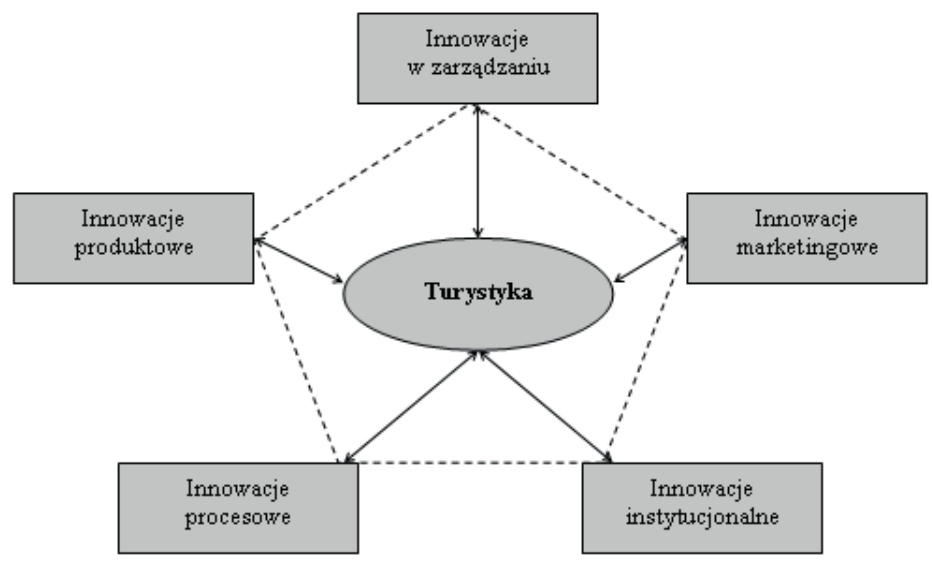

Ryc. 5. Rodzaje innowacji w turystyce

Źródło: na podstawie Hjalager, A.-M. (2010). A Review of Innovation Research in Tourism. Tourism Management, 31, 1-12 
Innowacje produktowe lub usługowe dotyczą zmian postrzeganych przez konsumenta jako nowe, zarówno w znaczeniu dotychczas niespotykane, jak i nowatorskie dla poszczególnych przedsiębiorstw czy destynacji turystycznych. Innowacje produktowe oraz usługowe w znacznym stopniu mogą przyczynić się do decyzji turysty o zakupie usługi.

Innowacje procesowe zazwyczaj dotyczą funkcjonowania zaplecza, czego głównym celem jest wzrost sprawności, wydajności oraz przepustowości poszczególnych operacji. Rozwiązania technologiczne oraz innowacje z nimi związane, będąc podstawą koncepcji innowacji procesowych, często wykorzystywane są razem z przebudowanym planem technicznym wykorzystywanych czynności manualnych. Dobrym przykładem tego rodzaju innowacji w turystyce mogą być rozwiązania procesowe w kuchniach poszczególnych restauracji.

Innowacje w sferze zarządzania dotyczą nowych form organizowania współpracy wewnętrznej, kierowania zespołem oraz delegowania zadań, rozwoju kariery oraz budowania odpowiedniego systemu wynagrodzeń. Dużym wyzwaniem dla wielu przedsiębiorstw turystycznych jest opracowanie metod ograniczenia rotacji pracowników, utrzymania elastyczności oraz kontroli kosztów.

Kolejnym rodzajem innowacji w turystyce są innowacje marketingowe. Przykładem takiego unowocześnienia w branży turystycznej jest wprowadzenie i rozwój programów lojalnościowych. Programy te występują w różnych odmianach oraz są bardzo powszechne, gdyż zasadniczo zmieniają relacje pomiędzy dostawcami usług turystycznych a ich klientami, budując długotrwałe więzi oparte na lojalności i dostarczając stałym klientom dodatkowych korzyści.

Ostatnim rodzajem innowacji identyfikowanych w turystyce są innowacje instytucjonalne. Może to być nowa struktura współpracy/organizacyjna lub forma prawna, która skutecznie zmienia lub usprawnia działalność firmy w poszczególnych działach turystyki. Poszczególne sieci firm odgrywają istotną rolę w rozwoju innowacji, również wśród małych i średnich przedsiębiorstw. Nowe instytucje mogą jednak powodować więcej zmian i tym samym wpływać na szersze grono przedsiębiorstw i konsumentów (Hjalager, 2010).

Wszystkie te zabiegi odnosić się mogą również do rynku turystyki osób niepełnosprawnych. Poprzez unowocześnienia zmarginalizowana grupa społeczna, jaką są osoby niepełnosprawne, może uczestniczyć w aktywnościach turystycznych i w pełni korzystać z dostępnych usług i produktów.

\section{OSOBY NIEPEŁNOSPRAWNE W GOSPODARCE TURYSTYCZNEJ OPARTEJ NA WIEDZY}

W nowym modelu funkcjonowania gospodarki turystycznej opartej na wiedzy klienci stają się integralną częścią rynku. Organizacje rozwijają się, tworząc innowacje produktowe na podstawie wiedzy tworzonej wewnątrz firmy turystycznej, wiedzy ukształtowanej przez bezpośrednie relacje z klientami i wiedzy z klientów (Januszewska, Nawrocka, 2010: 35). W takiej sytuacji osoby niepełnosprawne w społeczeństwie opartym na wiedzy stają się częścią oferty turystycznej oraz współtwórcami wartości dodanej na rynku. Osoby 
niepełnosprawne wpływają na organizację, kształtując innowacyjne usługi, produkty, których w rezultacie sami są odbiorcami (ryc. 6).

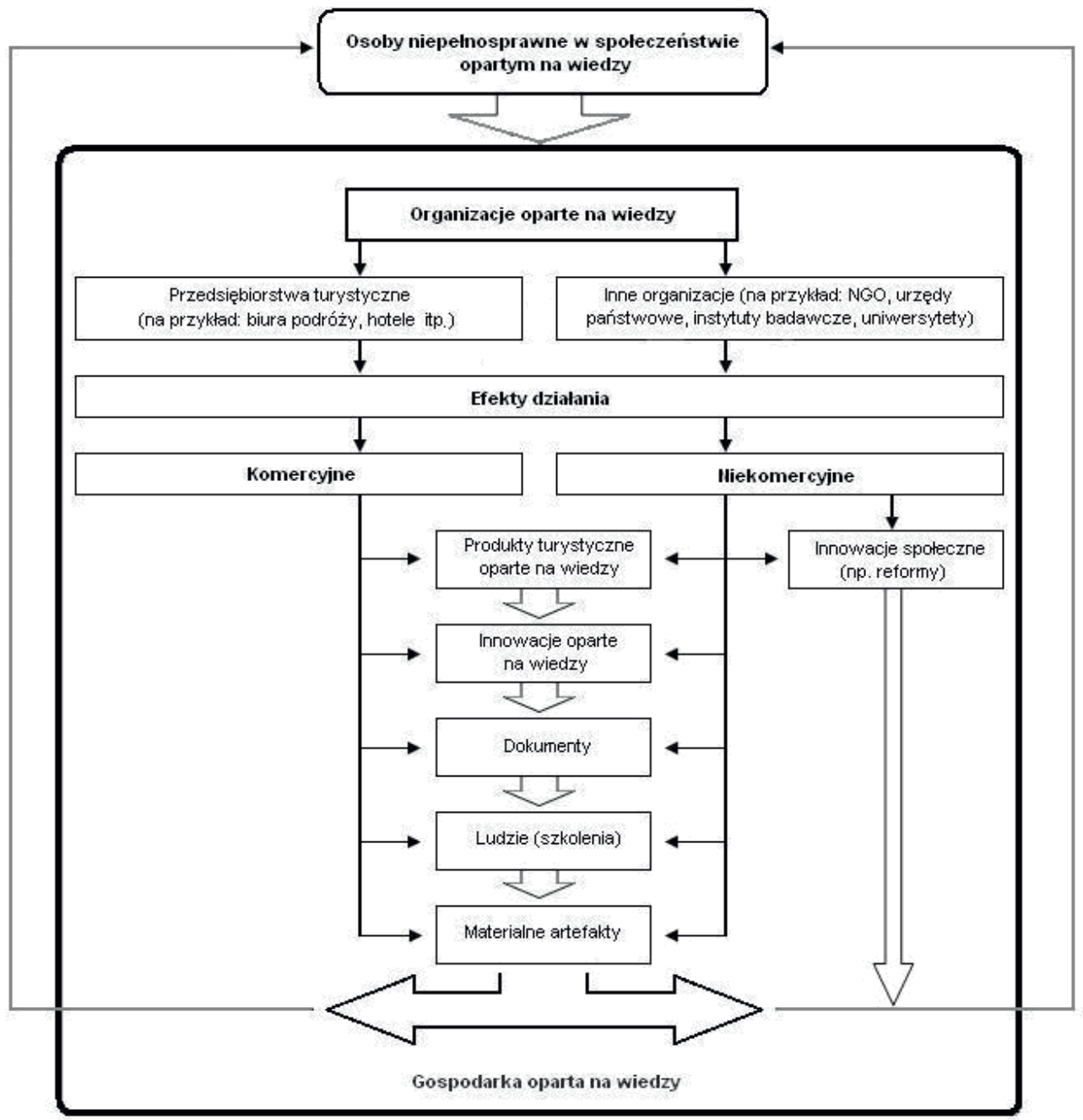

Ryc. 6. Osoby niepełnosprawne w gospodarce turystycznej opartej na wiedzy

Źródło: na podstawie Poskrobko, B. (red.) (2011). Gospodarka oparta na wiedzy. Białystok: Wyższa Szkoła Ekonomiczna

\section{DOBRE PRAKTYKI W ROZWOJU TURYSTYKI OSÓB NIEPEŁNOSPRAWNYCH}

Społeczeństwa na całym świecie dostrzegły konieczność podejmowania problematyki turystyki osób niepełnosprawnych. Powstaje coraz więcej usług, produktów turystycznych dostosowanych do potrzeb osób z dysfunkcjami. Relatywnie najlepsza sytuacja w tym względzie występuje w najbardziej rozwiniętych ekonomicznie i socjalnie krajach europejskich, 
jak Szwecja, Niemcy czy Włochy (Grabowski, 2008: 55). Idee mające na celu równouprawnienie i wyrównanie szans na podróżowanie upośledzonych grup społecznych, zainicjowane przez państwa członkowskie Unii Europejskiej, rozprzestrzeniły się na całym świecie i są twórczo rozwijane.

Pierwowzorem wszelkich projektów na rzecz dostępności turystyki dla osób niepełnosprawnych jest koncepcja „Turystyki dla Wszystkich”, zapoczątkowana W Wielkiej Brytanii w 1989 roku. Z założenia inicjatywa ta miała ułatwiać podróżowanie. Każdy - bez względu na rodzaj niepełnosprawności - powinien móc podróżować po swoim kraju czy wyjechać do innego państwa oraz zobaczyć rożne miejsca, atrakcje turystyczne lub wziąć udział w wydarzeniu (Grabowski, 2008).

Wiele organizacji oraz instytucji podejmuje się działalności na rzecz poprawy stanu osób z niepełnosprawnością. Działania te mają rożne założenia i charakter, jednakże wszystkie oparte są na wiedzy i mądrości. Poza jednostkowym, lokalnym dostosowywaniem usług turystycznych, powstaje szereg projektów o zasięgu ogólnoświatowym (ryc. 7).

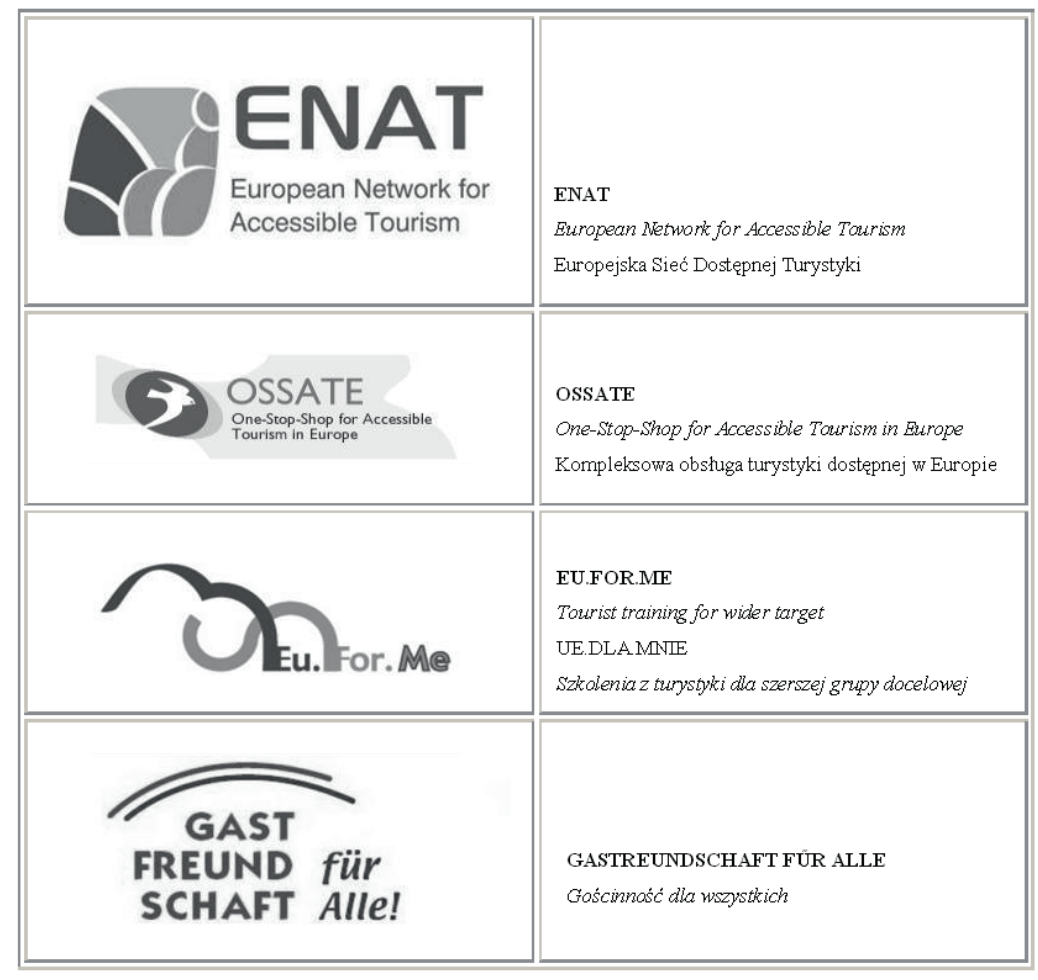

Ryc. 7. Logotypy i hasła wybranych projektów na rzecz rozwoju turystyki osób niepełnosprawnych w Europie

Źródło: na podstawie www.accessibletourism.org (dostęp: 12.12.2012), www.ossate.org (dostęp: 12.12.2012), www.euforme.net (dostęp: 12.12.2012), www.gastfreundschaft-fuer-alle.de (dostęp: 12.12.2012) 
CHARAKTERYSTYKA WYBRANYCH PROJEKTÓW MIĘDZYNARODOWYCH NA RZECZ ROZWOJU TURYSTYKI OSÓB NIEPEŁNOSPRAWNYCH

ENAT (European Network for Accessible Tourism - Europejska Sieć Dostępnej Turystyki) powstał w styczniu 2006 roku jako projekt na fundamencie inicjatywy 9 organizacji sponsorujących, pochodzących z 6 państw członkowskich UE. Nadrzędnym celem organizacji jest udostępnienie europejskich ośrodków turystycznych, produktów i usług wszystkim pasażerom oraz promowanie turystyki na całym świecie. ENAT dąży do tego celu poprzez platformę internetową, będącą miejscem wymiany opinii i doświadczeń, dzięki czemu zarówno turyści niepełnosprawni, jak i przedsiębiorstwa czy organizacje wspierające turystykę mogą wymieniać doświadczenia i współpracować. Promuje się szeroką świadomość i zrozumienie konieczności dostępu osób z dysfunkcjami do wszystkich usług turystycznych, z największym naciskiem na Europę, podnosząc tym samym standard „Turystyki dla wszystkich".

Pośród wielu przedsięwzięć podejmowanych przez organizację, takich jak: szkolenia, międzynarodowe kongresy, konferencje, największym jest strona internetowa www.accessibletourism.org. Stanowi ona źródło zarówno informacji o samym projekcie, turystyce osób niepełnosprawnych, jak również wiedzy z zakresu udostępniania obiektów i usług, z której korzystają turyści oraz przedsiębiorcy.

OSSATE (One-Stop-Shop for Accessible Tourism - kompleksowa obsługa turystyki dostępnej w Europie). Projekt powstał w 2005 roku i ma na celu stworzenie wielojęzycznej platformy, która zawiera informacje odnośnie dostosowanych miejsc turystycznych, zabytków, obiektów zakwaterowania, ułatwiając osobom niepełnosprawnym podróżowanie. Projekt współfinansowany jest przez Komisję Europejską w ramach programu „eContent”, który zakłada promocję produkcji, dystrybucji oraz użytkowania cyfrowych usług informacyjnych. Organizacje turystyczne i poszczególni dostawcy bezpośrednio wprowadzają dane do systemu, dzięki czemu turyści niepełnosprawni mogą odbierać informacje za pomocą portalu lub za pośrednictwem telefonów komórkowych. Usługa skierowana jest głównie ale nie tylko - do niepełnosprawnych obywateli Europy, gdyż wśród instytucji realizujących projekt pierwotnie znajdowały się organizacje rządowe, pozarządowe oraz ośrodki naukowo-badawcze z Belgii, Danii, Grecji, Norwegii, Szwecji oraz Wielkiej Brytanii. Szczególny nacisk położony został na kreowanie marki, projektowanie i promocję usług, aby zapewnić im szerokie uznanie i akceptację jako wiarygodnemu i przydatnemu źródłu wiedzy dla sektora turystycznego i użytkowników w całej Europie.

Istotną częścią portalu jest wyszukiwarka obiektów dostępnych dla osób niepełnosprawnych, która pozwala na wybór usług w oparciu o rożne kryteria. Turyści dodatkowo mogą sami oceniać obiekty za pomocą kwestionariuszy, dzięki czemu możliwe jest wykorzystanie ich wiedzy - nabytej w wyniku własnego doświadczenia - przez innych zwiedzających.

EU.FOR.ME (Tourist Training for Wider Target - szkolenia z turystyki dla szerszej grupy docelowej). Projekt został już zakończony, jednakże zasługuje na wyróżnienie ze względu na charakter edukacyjny. Zakładał stworzenie systemu szkoleniowego dotyczącego 
zagadnień związanych z dostosowywaniem usług i obiektów na podstawie identyfikacji potrzeb i wymogów osób niepełnosprawnych (Grabowski, 2008). Szkolenia skierowane były do szkół rożnych poziomów oraz szeroko pojętego sektora turystycznego.

Gastfreundschaft für Alle (Gościnność dla wszystkich) to projekt niemieckiego Stowarzyszenia Hoteli i Restauracji DEHOGA oraz Krajowego Komitetu Koordynującego „Turystyka dla Każdego”. Nacisk został położony na praktyczne przekazanie wiedzy o grupie osób niepełnosprawnych pracownikom branży hotelarskiej. Szkolenia obejmują tworzenie, wprowadzanie na rynek produktów i usług dostosowanych do potrzeb osób z dysfunkcjami oraz - co najważniejsze - sposób bezpośredniej obsługi niepełnosprawnego turysty.

\section{CHARAKTERYSTYKA WYBRANYCH INICJATYW NA RZECZ ROZWOJU TURYSTYKI OSÓB NIEPEŁNOSPRAWNYCH W POLSCE}

Po wejściu Polski do Unii Europejskiej coraz większy nacisk kładzie się w kraju na podejmowanie problematyki turystyki osób niepełnosprawnych. Efektem tego są rożne innowacje o zasięgu lokalnym lub krajowym, bazujące na wiedzy.

Przykładem dobrej praktyki na rzecz turystyki osób niepełnosprawnych może być działające od roku 2008 biuro podroży Accessible Poland, które prowadzone jest przez osobę niepełnosprawną od urodzenia. Wiedza tej osoby nabyta w procesie osobistego doświadczenia turystycznego poprzez liczne podróże po świecie, korzystanie z usług biur podroży ukierunkowanych na osoby z dysfunkcjami stała się impulsem do stworzenia innowacyjnego - jak na polski rynek turystyczny - biura, nastawionego na kompleksową obsługę osób niepełnosprawnych. Firma dociera do klientów poprzez internet, gdyż jest nastawiona szczególnie na osoby na wózkach inwalidzkich, których mobilność jest ograniczona. Ponadto świadczone są usługi w wyszukiwaniu i rezerwacji hoteli, ośrodków wczasowych oraz sanatoriów przyjaznych osobom z niepełnosprawnością (Skalska, 2010: 40-41). Poprzez swój profil oraz wykorzystanie zaawansowanej telekomunikacji biuro stało się innowacyjnym przedsiębiorstwem turystycznym opartym na wiedzy.

Turystyka dla wszystkich to projekt realizowany przez Polskie Towarzystwo Turystyczno-Krajoznawcze. Zasięg przestrzenny obejmuje całą Polskę. Zasadniczą częścią projektu jest strona internetowa, zawierająca wykaz atrakcji, elementów infrastruktury turystycznej, dostosowanych do potrzeb osób z niepełnosprawnością.

Unia Europejska również pomaga w szkoleniu personelu z branży turystycznej, hotelarskiej czy gastronomicznej w Polsce, mającego bezpośredni kontakt z niepełnosprawnymi turystami. Projekt Wielkopolska turystyka przyjazna niepelnosprawnym - trwający od kwietnia 2012 roku do sierpnia 2013 roku - był współfinansowany ze środków Unii Europejskiej w ramach Europejskiego Funduszu Społecznego. Głównym celem projektu było przekazanie 280 osobom praktycznej wiedzy na temat obsługi klienta niepełnosprawnego, w tym: nauka języka migowego, zapoznanie z definicją i rodzajami niepełnosprawności, 
obsługa turysty na żywo, przez telefon, e-mail czy sposoby niesienia pomocy. Jest to jeden z nielicznych projektów o charakterze szkoleniowym w Polsce, stąd jego innowacyjność.

Opisane powyżej projekty skupiają się głównie na dostarczaniu informacji bądź wprowadzaniu innowacji w celu jej dystrybucji (np. portale internetowe, szkolenia). Odpowiadają zatem jedynie na jeden, ale jakże ważny element rynku turystycznego, warunkujący aktywność turystyczną osób niepełnosprawnych (Grabowski, 2008: 60). Mało jest natomiast projektów skupiających się na materialnych elementach rzeczywistości. Ten spadek znaczenia zasobów materialnych na rzecz niematerialnych wynika przede wszystkim z przesłanek finansowych i organizacyjnych. Projekty trwałe, materialne artefakty są dużo bardziej kosztochłonne, stąd zasługują na jeszcze większe uznanie.

Przykładem takiego przedsięwzięcia jest projekt unijny Droga Królewska dla Niepelnosprawnego Turysty, zrealizowany przez Miasto Kraków. Jego wartość wyniosła 1220370 zł, z czego 922028 zł zostało przekazane przez Unię Europejską (www. bip.krakow.pl, dostęp: 12.12.2012). Głównym założeniem projektu było udostępnienie turystom niepełnosprawnym dziedzictwa kulturowego Krakowa poprzez stworzenie atrakcyjnej trasy turystycznej dostępnej dla osób z dysfunkcjami, w tym osób niewidomych i słabowidzących. W ramach projektu stworzono dwanaście makiet, prezentujących najciekawsze zabytki Krakowa (ryc. 8). Każda z nich zawiera opis eksponowanych atrakcji w alfabecie łacińskim oraz alfabecie Braille’a w dwóch wersjach językowych - polskiej i angielskiej. Dziewięć makiet jest ustawionych na postumentach, dzięki czemu możliwy jest dojazd do nich na wózkach inwalidzkich, natomiast trzy makiety to elementy wiszące, umieszczone nisko z myślą o dostępności dla osób na wózkach. W ramach projektu przygotowano także specjalistyczny opis Drogi Królewskiej oraz prezentowanych atrakcji w wersji audio, z przeznaczeniem głównie dla osób niewidomych. Nagranie jest dostępne w dwóch wersjach językowych: polskiej i angielskiej. Dodatkowo udostępniono turystom - posiadającym telefony komórkowe z anteną satelitarną GPS lub modułem Bluetooth komunikaty audio, które można bezpłatnie pobierać ze strony internetowej Gminy Miasta Kraków. Przedsięwzięcie to zostało wyróżnione w 2011 roku nagrodą w konkursie Fundacji Instytut Rozwoju Regionalnego „Samorząd równych szans” jako pierwszy tak innowacyjny projekt w Polsce oparty na wiedzy na rzecz rozwoju turystyki osób niepełnosprawnych.

W przeprowadzonym do celów artykułu badaniu ankietowym wśród 250 respondentów niepełnosprawnych z terenu Krakowa znalazło się 27 osób (11\%) z chorobami narządu wzroku (ryc. 9). Według założeń krakowskiego projektu to właśnie z myślą o tej grupie społecznej powstało przedsięwzięcie. Pytane o odczucia wobec opisanej innowacyjnej usługi, jednomyślnie wyraziły się pozytywnie na jej temat, wskazując na racjonalne wykorzystanie wiedzy o ich potrzebach związanych z dostosowaniem rynku turystycznego. 


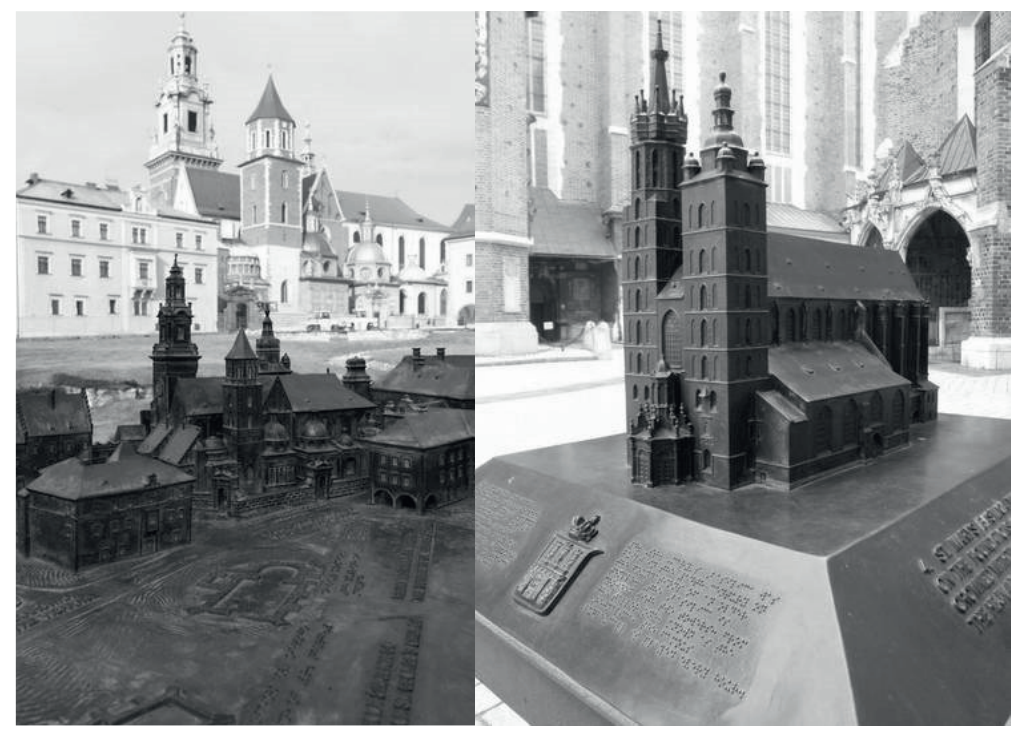

Ryc. 8. Makiety dla niewidomych w Krakowie

Źródło: www.ue.krakow.pl (dostęp: 12.12.2012)

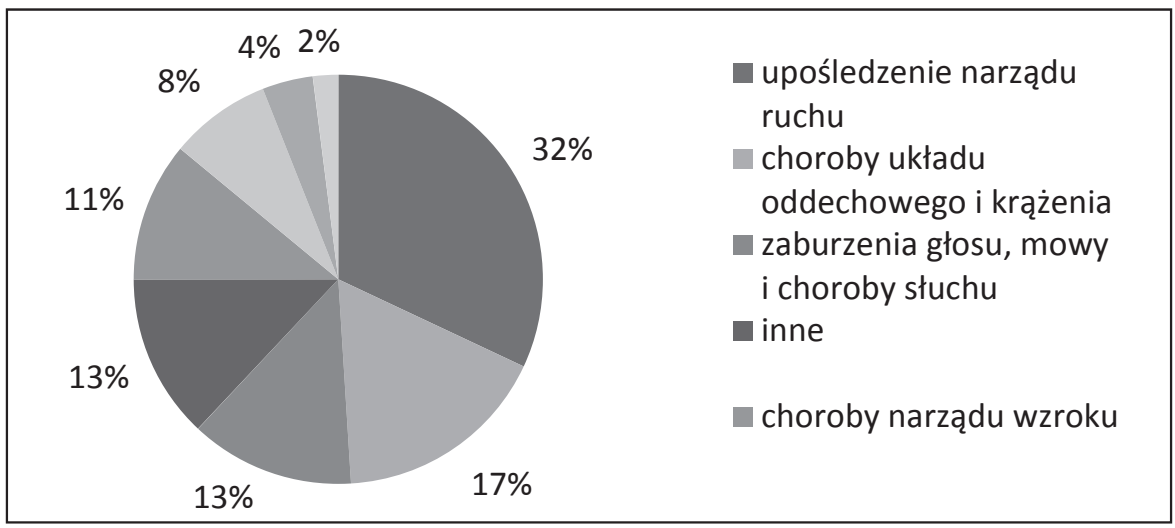

Ryc. 9. Struktura badanych respondentów z niepełnosprawnością $(\mathrm{N}=250 \mathrm{os}$.)

Źródło: opracowanie własne

\section{Podsumowanie}

Społeczeństwa w gospodarce opartej na wiedzy stają się coraz bardziej świadome potrzeb osób doświadczających ograniczenia mobilności, które odczuwają potrzebę odkrywania miejsc i doświadczenia przyjemności, jakie niesie za sobą podróżowanie. Proces wiodący 
do dostępności turystyki jest bardzo ważny, gdyż stanowi ona integralną część gospodarki i społeczeństwa. Biorąc pod uwagę obecną sytuację w zakresie podaży i popytu na podróżowanie, ważne jest, by udostępniać turystykę dla dużej liczby potencjalnych turystów, jakimi są osoby niepełnosprawne. Dokonać tego można poprzez zapewnienie dostępności usług dla wszystkich typów wymagań klientów, w zależności od rodzaju upośledzenia. Ważnym wymogiem jest przy tym dostarczenie informacji, której efektywne przekształcenie w wiedzę może skutkować innowacyjnymi rozwiązaniami, skierowanymi do osób niepełnosprawnych. Powstaje szereg projektów o zasięgu międzynarodowym czy krajowym, głównie zainicjowanych przez sektor publiczny, jednakże wartość dodana usług na rynku turystyki osób z dysfunkcjami może być świadczona przez szereg dostawców. Udostępnienie usług, produktów, obiektów na potrzeby osób niepełnosprawnych niesie nie tylko korzyści dla samych zainteresowanych turystów, ale i dla przedsiębiorstw, poprzez wzrost konkurencyjności podmiotów turystycznych i umożliwienie poprawy jakości przemysłu turystycznego oraz świadczonych usług dzięki dopasowaniu podaży do oczekiwań wymagających klientów niepełnosprawnych. Ogromne znaczenie ma zwiększenie świadomości potrzeb rynku dostępnej turystyki oraz korzyści gospodarczych, możliwych do osiągnięcia poprzez oferowanie odpowiednich rozwiązań. Głównym wyzwaniem jest fakt, że aktywność turystyczna rozpoczyna się od decyzji odbycia podróży i kończy się powrotem do domu, skupiając ogromny łańcuch produktów i usług pomiędzy, stąd tak ważna jest wiedza i przekaz informacji na temat dostępności każdego elementu tego łańcucha.

Wspomniane w artykule pozytywne praktyki na rzecz rozwoju turystyki osób niepełnosprawnych w państwach europejskich są dobrym impulsem do dalszych przedsięwzięć, mających pomóc w udostępnianiu turystyki dla wszystkich. Generują one oraz poprawiają współpracę między różnymi podmiotami gospodarki, dzięki czemu następuje poprawa sytuacji osób niepełnosprawnych na rynku turystycznym, dając szansę na pełną aktywizację tej grupy społecznej.

\section{Literatura}

Barczyński, M. (red.). (1993). Medyczny Stownik Encyklopedyczny. Kraków: Oficyna Wydawnicza „Fogra”.

Buhalis, D., Darcy, S., Ambrose, I. (2012). Best Practice in Accessible Tourism. Inclusion, Disability, Ageing Population and Tourism, New York: Channel View Publications.

Burnett, J.J., Bender-Baker, H. (2001). Accessing the Travel-related Behaviors of the Mobility-disabled Consumer. Journal of Travel Research, 40(1), 4-11.

Darcy, S., Daruwalla, P.S. (1999). The Trouble with Travel: People with Disabilities and Tourism. Social Alternatives, 18(1), 41-46.

Economic Impulses on Accessible Tourism for All. (2004). Nr 526. Berlin: Federal Ministry of Economics and Labour.

Grabowski, J. (2008). Projekty na rzecz rozwoju turystyki osób niepełnosprawnych. W: A. Stasiak (red.). Rola krajoznawstwa i turystyki w życiu osób niepetnosprawnych. Warszawa: Wydawnictwo PTTK „Kraj”.

Halemba, P., Hermaciński, R. (2009). Sport i turystyka osób niepetnosprawnych. Kielce: Wyższa Szkoła Umiejętności im. Stanisława Staszica. 
Hjalager, A.-M. (2010). A Review of Innovation Research in Tourism. Tourism Management, 31, 1-12. Hulek, A. (1969). Teoria i praktyka rehabilitacji inwalidów. Warszawa: Wydawnictwo Lekarskie PZWL.

Januszewska, M., Nawrocka, E. (2010). Innowacyjne przedsiębiorstwo turystyczne oparte na wiedzy. W: K. Rogoziński, A. Panasiuk (red.). Zarządzanie organizacjami ustugowymi. Zeszyty Naukowe UE w Poznaniu 2010, nr 145. Poznań: Wydawnictwo UE w Poznaniu, 35-48.

Kaganek, K. (2009). Turystyka osób niepetnosprawnych $w$ aspekcie wybranych uwarunkowań. Kraków: European Association for Security.

Majewski, T. (1995). Rehabilitacja zawodowa osób niepetnosprawnych. Warszawa: Centrum Badawczo-Rozwojowe Rehabilitacji Osób Niepełnosprawnych.

Ostrowska, A. (1994). Badania nad niepetnosprawnościa w Polsce. Warszawa: PAN.

Popiel, M. (2012). Turystyka studentów niepełnosprawnych na przykładzie krakowskich uczelni wyższych. W: M. Sokołowski, A. Kaiser, J. Brzozowski (red.). Holicystyczna koncepcja zdrowia w turystyce i rekreacji. Poznań: Wielkopolska Wyższa Szkoła Turystyki i Zarządzania w Poznaniu, 171-190.

Porter, M.E. (2006). Przewaga konkurencyjna: osiaganie i utrzymywanie lepszych wyników. Gliwice: Helion.

Poskrobko, B. (red.). (2011). Gospodarka oparta na wiedzy. Białystok: Wyższa Szkoła Ekonomiczna. Repetowski, R. (2008). Rola innowacji w funkcjonowaniu przedsiębiorstw przemysłowych. Prace Komisji Geografii Przemystu Polskiego Towarzystwa Geograficznego, 10, 173-187.

Skalska, T. (2010). Nowe wyzwania gospodarki turystycznej. Turystyka osób niepetnosprawnych: porady dla ustugodawców. Warszawa: Szkoła Wyższa Przymierza Rodzin.

\section{Źródla internetowe}

UNWTO. UNWTO Annual Report 2012, http://www.unwto.org (dostęp 12.12.2012).

World Health Organization. World Report on Disability 2011, http://www.who.int. (dostęp 12.12.2012) www.bip.krakow.pl (dostęp 12.12.2012)

www.euforme.net (dostęp 12.12.2012)

www.gastfreundschaft-fuer-alle.de (dostęp 12.12.2012)

www.ue.krakow.pl (dostęp 12.12.2012)

www.un.org (dostęp 12.12.2012)

www.unwto.org (dostęp 12.12.2012)

Marcin Popiel, mgr, Uniwersytet Jagielloński, Instytut Geografii i Gospodarki Przestrzennej.

Geograf, pilot wycieczek, zapalony turysta. Absolwent geografii Uniwersytetu Pedagogicznego w Krakowie. Od 2012 roku doktorant Uniwersytetu Jagiellońskiego na Wydziale Biologii i Nauk o Ziemi. Interesuje się badaniami nad atrakcjami turystycznymi oraz regionalizacją turystyczną. Specjalizuje się w zakresie innowacyjności i zarządzania w turystyce i hotelarstwie.

Marcin Popiel, geographer, tour leader, for whom traveling is a great passion. Graduated geography at the Pedagogical University in Krakow. From 2012 a PhD student at the Jagiellonian University, Faculty of Biology and Earth Sciences. Is interested in the study of regionalization and tourism attractions. Specializes in the field of innovation and management in tourism and hospitality.

adres/address: Uniwersytet Jagielloński

Instytut Geografii i Gospodarki Przestrzennej

ul. Gronostajowa 7, 30-387 Kraków, Polska

e-mail: marcin.popiel@uj.edu.pl 